\title{
The Magnitude and Relevance of the February 2014 Radiation Release from the Waste Isolation Pilot Plant Repository in New Mexico, USA.
}

\author{
P.Thakur ${ }^{1}$, B.G. Lemons ${ }^{1}$, and C.R. White ${ }^{2}$ \\ 1. Carlsbad Environmental Monitoring \& Research Center, 1400 University Drive, \\ Carlsbad, New Mexico-88220, USA. \\ 2. AECOM, Carlsbad Operations, Carlsbad, New Mexico-88220, USA.
}

\begin{abstract}
After almost fifteen years of successful waste disposal operations, the first unambiguous airborne radiation release from the Waste Isolation Pilot Plant (WIPP) was detected beyond the site boundary on February 14, 2014. It was the first accident of its kind in the 15-year operating history of the WIPP. The accident released moderate levels of radioactivity into the underground air. A small but measurable amount of radioactivity also escaped to the surface through the ventilation system and was detected above ground. The dominant radionuclides released were americium and plutonium, in a ratio consistent with the known content of a breached drum. The radiation release was caused by a runaway chemical reaction inside a transuranic (TRU) waste drum which experienced a seal and lid failure, spewing radioactive materials into the repository.

According to source-term estimation, approximately 2 to $10 \mathrm{Ci}$ of radioactivity was released from the breached drum into the underground, and an undetermined fraction of that source term became airborne, setting off an alarm and triggering the closure of seals designed to force exhausting air through a system of filters including highefficiency-particulate-air (HEPA) filters. Air monitoring across the WIPP site intensified following the first reports of radiation detection underground to determine the extent of impact to WIPP personnel, the public, and the environment, if any. This article attempts to compile and interpret analytical data collected by an independent monitoring program conducted by the Carlsbad Environmental Monitoring \& Research Center (CEMRC) and by a compliance-monitoring program conducted by the WIPP's management and operating contractor, the Nuclear Waste Partnership (NWP), LLC., in response to the accident. Both the independent and the WIPP monitoring efforts concluded that the levels detected were very low and localized, and no radiation-related health effects among local workers or the public would be expected.
\end{abstract}




\section{Introduction}

The Waste Isolation Pilot Plant (WIPP) is the nation's only deep geologic repository designed to dispose of transuranic, or TRU waste generated primarily from the research and production of nuclear weapons. TRU waste is defined as "waste containing more than $100 \mathrm{nCi}$ of alpha-emitting TRU isotopes per gram of waste, with half-lives greater than 20 years." In 1979, Congress authorized the design and construction of WIPP, planned to provide permanent isolation of all long-lived transuranic radioactive wastes from the production of nuclear weapons. Located near Carlsbad, New Mexico, the repository is mined in the Salado Formation, a Permian bedded halite formation, and waste is emplaced approximately $655 \mathrm{~m}$ below the land surface, approximately in the center of the deep bedded salts of the Permian Basin.

Disposal in the salt deposits was chosen mainly because massive salt deposits have extremely low hydraulic conductivity, i.e. no flowing water that could move the waste out of the repository environs and to the surface. Salts are also relatively easy to mine. Additionally, rock salt at depth heals its own fractures because of its plasticity and will slowly and progressively move in to fill mined areas and thereby seal the radioactive waste from the environment. Twenty years after its authorization by Congress, the Waste Isolation Pilot Plant (WIPP) received its first shipments of TRU waste for permanent disposal in March 1999, and has since disposed of more than 86,000 cubic meters of Cold-War legacy TRU waste in more than 165,000 containers, cleaning up 22 generator sites nationwide. Over its lifetime, WIPP is expected to dispose of approximately 175,000 cubic meters of TRU waste from various DOE sites. The WIPP is about half full in terms of its legally defined capacity.

As shown in supplementary material Figure S1, the WIPP repository layout currently has eight panels planned, each consisting of seven waste disposal rooms approximately 91 meters long and 10 meters wide. The rooms are filled with waste moving from back to front (Room 7 first), and filled panels are sealed. Seven of the panels have been excavated; and the first six have been closed and sealed from ventilation air. Panel 7 is the current active waste disposal area. Waste disposal was in progress in the seventh panel, in its Room 7, where the release event occurred on February 14, 2014. Room 7 of Panel 7 was closed shortly after the accident investigation concluded, to seal it off from 
underground air circulation. Disposal operations at WIPP are planned to resume late in 2016.

The facility also consists of above-ground waste receipt and handling facilities, common drifts for access and ventilation, and four shafts connecting surface operations to underground emplacement activities. The air intake and exhaust shafts provide the necessary air circulation for the underground. The air intake shaft provides the greatest percentage of air to the underground. The salt handling shaft is used to remove mined salt from the underground and also serves as an air intake shaft. The waste handling shaft is used to transport TRU waste containers (as well as personnel, supplies and equipment) into the underground for use and emplacement.

The radionuclides of greatest concern in the WIPP are ${ }^{239} \mathrm{Pu},{ }^{240} \mathrm{Pu}$, and ${ }^{241} \mathrm{Am}$, which account for more than $99 \%$ of the total radioactivity scheduled for disposal in the repository. The repository is ventilated by drawing in a large amount of outside air. Since the air in the repository exits to the surface through its exhaust shaft, this shaft is the sole potential pathway for airborne radioactivity release from the WIPP. During normal operations, exhaust air is released unfiltered. Since the underground release event exhaust air is being filtered through a bank of filters including High Efficiency Particulate Air (HEPA) filters prior to release at the surface. This capability was part of the original design of the repository and in case of a detected release is automatically engaged to prevents or minimize above-ground releases to protect above-ground onsite personnel and the public away from the site. Continuous air monitors underground control whether or not the ventilation returning to the surface is passed through these large filter systems before it is released to the atmosphere. Since the February 2014 event, WIPP has been, and will remain in what is called "filtration mode," which limits underground airflow and hence underground activity.

\section{Independent Monitoring and WIPP}

Environmental monitoring is a key component in the development and operation of any nuclear facility. Well after the WIPP facility had been sited and constructed, but before repository operations began, DOE and local community leaders recognized the value of having an independent environmental monitoring program in maintaining community support for the WIPP project. In 1991, DOE funded New Mexico State 
University (NMSU) to build and operate a state-of-the-art environmental monitoring facility in Carlsbad, the Carlsbad Environmental Monitoring and Research Center (CEMRC). The purpose of CEMRC was to independently establish a baseline before operations began, and then evaluate the radiological fingerprint of the facility in its environmental setting throughout its operational lifetime.

CEMRC has been conducting independent health and environmental monitoring in the vicinity of WIPP since 1995 and has made the results easily accessible to all interested parties (www.cemrc.org) . Public access to the monitoring data and their ability to directly participate in CEMRC's whole body counting program provides a key element of trust and transparency for the public. CEMRC is funded by DOE through a grant process that respects its independence in carrying out and reporting the results of environmental monitoring at and near the WIPP site. In addition to CEMRC's independent monitoring, the site is also monitored by WIPP's management and operating contractor, the Nuclear Waste Partnership, LLC (NWP) as well as the New Mexico Environmental Department (NMED). This review is based on the more complete monitoring data sets completed by CEMRC and NWP.

\section{The Two Incidents at WIPP in February, 2014}

On February 5, 2014 at approximately 10:45 am (Mountain Standard Time, MST), a truck used to remove mined salt from the underground facility caught on fire in the northern part of the WIPP underground, resulting in evacuation of the mine. The fire burned the engine compartment of the salt haul truck and consumed the front tires, which contributed significantly to the amount of smoke and soot in the area of the fire (www.wipp.energy.gov) . All 86 workers underground at the time of the fire safely evacuated. The underground portion of WIPP was shut down. Six workers were treated for smoke inhalation, but no injuries occurred. Fortunately, no radioactive waste was impacted by this fire because the fire occurred at a considerable distance from the waste. However, the heavy smoke from the fire caused damage by depositing soot on mechanical and electrical equipment and systems throughout the underground. Soot was deposited on the mine's walls, shafts, and underground equipment, including the waste 
hoist tower, which is used to transport TRU waste containers, personnel, and equipment to the underground for disposal.

On February 7, 2014, the Department of Energy appointed an Accident Investigation Board (AIB) to determine the cause of the fire incident and to develop recommendations for corrective actions to prevent recurrence. The AIB report on the haul truck fire was issued in March 7, 2014 (DOE, 2014a). The report cited inadequate training and poor maintenance as having contributed to the fire event and to problems with response to the fire.

Nine days later, on Friday, February 14 at 11:13 pm MST, a second but unrelated event occurred, which resulted in the release of americium and plutonium isotopes from one of the TRU waste container into the underground environment (www.wipp.energy.gov). The release was detected by an underground continuous air monitor (CAM) located near panel 7 where waste was being emplaced. The waste emplacement operations had been suspended nine days earlier because of the February 5, 2014 fire incident. As soon as the CAM alarmed on the night of February 14, the WIPP's ventilation system automatically switched to the filtration mode, reduced the air flow, and directed the exhaust air stream through the filter banks when it reached the surface. The ventilation system has been operating in filtration mode since that time. This automated actuation of "filtration mode" is intended to protect above ground workers at the site and the public in the surrounding areas by minimizing radiation releases to the environment in the event of a radioactive release occurrence underground.

The ventilation system appeared, at the time, to be functioning as designed, so there was no reason to suspect any substantial release to the environment. However, a small portion of the contaminated air bypassed the HEPA filters via leakage through imperfectly sealing ventilation system dampers and was discharged directly to the environment from an exhaust duct. The dampers have since been sealed off with highdensity expanding foam insulation. Since this incident occurred during the night, only a few employees were at the WIPP site and no employees were in the underground. Personnel were frisked and none were determined to have received external contamination; however, 21 individuals were identified through bioassay as having initially tested positive for low level amounts of internal contamination. All follow-up 
tests were below the detectable limits of the laboratory analysis indicating no long-term adverse health effects are expected for these employees. Trace amounts of americium and plutonium were detected off-site by CEMRC.

Soon after the radiation release events, the Department of Energy- Office of Environmental Management (DOE-EM) appointed a second Accident Investigation Board (AIB) to determine the cause of the radiation release and to develop recommendations for corrective actions. This second AIB released its findings in two phases. The Phase-1 report included initial investigations of the atmospheric release from the WIPP underground and related exposure to workers above ground, as well as the operational and emergency response to the radioactive release. The results were published on April 24, 2014 (DOE, 2014b). The Phase-2 report (DOE, 2015a) examined the cause of the 2014 radiological release event at WIPP. Based on post-event chemical, radiological, and fire forensic investigations, the report concluded that the release was caused by a runaway chemical reaction inside a TRU drum (drum \# 68660). This drum contained nitrate salt-bearing transuranic TRU waste that originated from Los Alamos National Laboratory. There was no indication of release from any other waste containers.

A Technical Assessment Team (TAT) of experts from US National Laboratories was also set up to perform a comprehensive, independent scientific review of the mechanisms and chemical reactions that may have contributed to the radioactive release (TAT report, 2015). The TAT report concluded that one drum, Drum 68660, was the source of radioactive contamination in WIPP. The contents of Drum 68660 were chemically incompatible, and the drum breached as a result of internal chemical reactions.

Air monitoring across the WIPP site intensified following the first reports of radiation detection underground to determine the potential impact on WIPP personnel, the public, and the environment. This review utilizes the monitoring data collected by CEMRC and by NWP to assess these potential impacts. The use of this data to evaluate the relationships between the contamination and the source using isotopic signatures is also discussed.

\section{Experimental Methods}

Underground Air Samples Collection 
Underground air samples were collected from Station A and Station B. Station A samples the unfiltered underground exhaust air, while Station B samples the underground exhaust air after filtration and, sometimes, non-filtered air during maintenance. Each station is a fixed air sampler, collecting particulates from the underground air on a Versapor filter (3.0- $\mu \mathrm{m}$ pore size and $47-\mathrm{mm}$ diameter, PALL Corporation). The detail of the WIPP underground sampling process and the sampling frequency are given in Supplementary material.

\section{Ambient Air Samples Collection}

The CEMRC operates a network of continuously operating samplers at three locations in the vicinity of the WIPP site. These monitoring stations are located at: (1) Onsite, which is about $0.1 \mathrm{~km}$ northwest (down prevailing wind) of the WIPP exhaust shaft, (2) Near Field, about 1 km northwest of the facility; and (3) Cactus Flats, about 19 $\mathrm{km}$ southeast (up prevailing wind) of the WIPP site. These sampling locations are shown in supplementary material Figure S2 (Top). Ambient aerosols were and are still collected using high volume samplers (flow rate $\sim 1.13$ cubic meters per minute) from three monitoring stations: These sites were selected based on an analysis of the most probable scenario for radioactivity release if there was an accidental release during the operation of

the WIPP. The aerosol samples were collected on $20 \times 25 \mathrm{~cm} \mathrm{~A} / \mathrm{E}^{\mathrm{TM}}$ glass fiber filters (Pall German Laboratory, Ann Arbor, MI). Under normal operating conditions, these filters were collected over a period of 3 to 6 weeks depending on the levels of particulate matter that accumulated on the filters. Following the radiation release event, filters were being changed and analyzed weekly. At the time this publication was being prepared, the sampling frequency is back to what it was prior to the event.

Additionally, NWP operates seven low-volume air samplers in the WIPP vicinity (ASER report, 2011). These monitoring stations are located at Carlsbad (CBD), Smith Ranch (SMR), Mills Ranch (MLR), WIPP South (WSS), WIPP East (WEE), WIPP Far Field (WFF), and the Southeast Control sites (SEC). The samples are collected at a height of 1.5 to $2 \mathrm{~m}$. The Southeast Control site is located approximately $19 \mathrm{~km}$ southeast of 
WIPP. This air sampling location is in the predominant upwind direction of WIPP. These sampling locations are illustrated in supplementary material Figure S2 (Bottom).

Weekly filter samples are typically collected at these sampling locations. Each week at each sampling location, approximately $600 \mathrm{~m}^{3}$ of air is sampled through a 47 centimeter diameter glass micro-fiber filter. Following the radiation release event, NWP deployed additional air monitors at or near the WIPP site and accelerated sampling and analysis frequency. The ambient air samples continue to be collected weekly from these sampling locations, but are analyzed as monthly composites. The detailed radiochemical methods for separation of individual actinides are described in the supplementary materials.

\section{Origin of Nitrate-salt Suspect Waste Stream}

This discussion is based on the work reported in the (TAT Report, 2015). The legacy nitrate salt wastes were generated from plutonium recovery operations at LANL in the nineteen-seventies and -eighties. Nitric acid dissolution operations were conducted in order to recover plutonium from scrap and residues, and the use of ion-exchange and oxalate precipitation produced a purified plutonium oxide product that could be further converted into plutonium metal. As with all plutonium processes, an anion-exchange process does not remove all the plutonium from solution, and thus the nitric acid solutions always contain small amounts of plutonium after they have passed through the anion-exchange process. These contaminated nitric acid effluents from the column process were collected in tanks and sent to evaporators in batches of up to 600 liters. The solution batches were then concentrated to approximately 25 liter volumes, called "bottoms." The "bottoms" were cooled to room temperature which produced the nitrate salts and a liquid supernate. The liquid was separated from the salts by filtration using a 200 mesh stainless steel screen. After filtration, the salts were washed with concentrated nitric acid, air dried, and packaged in double bags, and then placed in polyethylene liners within lead-lined 55-gallon drums. Filteraid ${ }^{\circledR}$ absorbent was then added to absorb any moisture. Nitrate salts produced from oxalate precipitation effluents were washed with water and not with nitric acid because nitric acid would accelerate decomposition of any oxalic acid presents in the salts and could result in pressurization of the sealed 55-gallon drums containing the salts with oxalate prior to air drying and packaging for storage. In 
addition to $\mathrm{Am}, \mathrm{Pu}, \mathrm{U}$ and minor amounts of other radionuclides, the waste is also expected to contain heavy metals such as cadmium, chromium, and lead and various metal-nitrate salts (strong oxidizers), such as $(\mathrm{Mg}, \mathrm{Ca})\left(\mathrm{NO}_{3}\right)_{2}$ with minor amounts of $\mathrm{Fe}$, $\mathrm{Na}$ and $\mathrm{K}$.

\section{Content of the Breached Drum}

The nitrate salt waste that was repackaged into drum 68660 was a portion of parent drum S855793. Two sibling drums (68660 and 68685) were produced during processing of the parent drum. Drum 68660 (65\% full) was shipped to WIPP. Drum 68685 (85\% full) is currently at Los Alamos and has a similar content to the processed nitrate salt layer in drum 68660. Head gas has been monitored and the sibling drum temperature has not increased significantly. Parent drum S855793 was generated in October 1985 and reportedly contained 14 plastic bags of nitrate salts, four of which resulted from an oxalate precipitation process. The parent waste still had some liquid nitric acid. WIPP cannot take liquid wastes. So, during repackaging operations an organic cat litter (Swheat Scoop®) composed of $100 \%$ wheat product was used to absorb free liquids and triethanolamine (TEA) was used as a neutralizing agent. The original procedure stated that "Kitty Litter/Zeolite clay" (Inorganic zeolite) was to be used as absorbent, TEA is part of the KOLORSAFE® liquid acid neutralizer that was also used before the procedure change. A tungsten lined glovebox glove was added to drum 68660 as a secondary waste. Some other secondary waste generated during remediation and repackaging operations such as Fantastik® bottles used during decontamination, miscellaneous hand tools, paper/plastic tags and labels, plastic/metal wire ties, personal protective equipment, plastic sheeting used for contamination control, rags and wipes (Kimwipes) were also put into the drum.

The detailed chemical composition of the nitrate salt waste contained in Drum 68660 does not exist. However, the (TAT Report, 2015) discussed the analysis of nitrate salt samples taken from two unprocessed drums, produced by the same process in the nineteen-eighties, and indicated that the predominant metals expected to be in drum 68660 include the alkali $(\mathrm{Na}, \mathrm{K})$ and alkaline earth $(\mathrm{Mg}, \mathrm{Ca})$ elements with minor amounts of other transition metal ( $\mathrm{Fe}, \mathrm{Cr}, \mathrm{Ni}, \mathrm{Zn})$, main group ( $\mathrm{Al}, \mathrm{Pb})$, and actinide elements. Although the nitrate content of each sample was similar, the concentrations of 
metals varied considerably. For example, the sodium and calcium concentrations varied by factors of 2.8 and 300 , respectively. The variation in elemental composition is not unexpected given the variety of materials processed in the plutonium processing facilities at the Los Alamos National Laboratory. The radiological constituents in the drum include ${ }^{241} \mathrm{Am},{ }^{243} \mathrm{Am},{ }^{237} \mathrm{~Np},{ }^{238} \mathrm{Pu},{ }^{239} \mathrm{Pu},{ }^{240} \mathrm{Pu},{ }^{241} \mathrm{Pu}$, and ${ }^{242} \mathrm{Pu}$, and the total radiological inventory in the drum was estimated by both the TAT and the AIB. Their estimates varied considerably: $1.78 \times 10^{11} \mathrm{~Bq}$ (4.81Ci) according to Table 6-12 of (DOE, 2015a) and from about $2.22-4.07 \times 10^{11} \mathrm{~Bq}$ (6 to $11 \mathrm{Ci}$ ) of just ${ }^{239+240} \mathrm{Pu}$ and ${ }^{241} \mathrm{Am}$ in Tables E-7 and E-9 of (TAT report, 2015). The gram quantities given in the TAT report were here converted to Curies. The TAT data are based on an uncertain reconstruction using twenty year old data, while the AIB data are based on Non-destructive analyses (NDA) using gamma measurements performed on the actual drum. Hence the AIB report inventory in their Table 6-12 is arguably the more reliable estimate. However, in estimating an airborne source term in Panel 7 Room 7, the AIB does not refer to the Table 6-12 inventory:

The 0.1 PE-Ci source term at Station A can be divided by the range of 0.01 to 0.05 LPFs (leakpath factor from the WIPP experiment) to estimate the range of source terms initially released in Panel 7 Room 7. This results in a range of 2 to $10 \mathrm{PE}-\mathrm{Ci}$ airborne in the room. Compared to the inventory in drum 68660 of $2.84 \mathrm{PE}-\mathrm{Ci}$, the release parameters (ARF and fraction of drum expelled) would range from about 70 percent to 100 percent of the drum contents plus contributions from additional waste containers breached to total 10 PE-Ci (DOE, 2015a).

The isotopes of ${ }^{241} \mathrm{Am}$ and ${ }^{239} \mathrm{Pu}$ and ${ }^{241} \mathrm{Pu}$, account for about $97 \%$ of drum 68660 's radioactive inventory as given in Table 6-12 of (DOE, 2015a). But the above discussion of a source term by the AIB focuses on an inventory term for drum 68660 of " $2.84 \mathrm{PE}$ Ci” [Plutonium Equivalent Curies], an inhalation-toxicity parameter with all actinides normalized to ${ }^{239} \mathrm{Pu}$ inhalation toxicity. This selected inventory value closely corresponds to the use of only the ${ }^{239} \mathrm{Pu},{ }^{240} \mathrm{Pu}$, and ${ }^{241} \mathrm{Am}$ in Table 6-12 of (DOE, 2015a) since the inhalation toxicity factor for ${ }^{241} \mathrm{Pu}$ is 51 times lower than for ${ }^{239} \mathrm{Pu}$, essentially knocking it out as a contributor to the PE-Ci total. 
This is problematic since Table 6-12 suggests ${ }^{241} \mathrm{Pu}$ was present in the drum at about the same activity level as ${ }^{241} \mathrm{Am}$, and it was detected at Station A. This makes the use of PE-Ci problematic as a unit for estimating the in-room source term from drum 68660. Using the $0.1 \mathrm{Ci}$ estimate for a Station A source term as if it were 0.1PE-Ci, as was done, would only work if there is not a major contribution to the release from ${ }^{241} \mathrm{Pu}$. If ${ }^{241} \mathrm{Pu}$ is released at a significant activity level, but plays virtually no role in the PE-Ci assumed to be the source-term from drum 68660, the estimate is not credible.

The PE-Ci is a calculated term used to estimate inhalation toxicity from releases, not a quantity that can be compared to estimate source terms. Summing the Table 6-12 drum curies for $\mathrm{Am}$ and $\mathrm{Pu}$ isotopes gives $1.78 \times 10^{11} \mathrm{~Bq}$ (4.81Ci). The Station $\mathrm{A}$ estimated source term of $3.7 \times 10^{9} \mathrm{~Bq}(0.1 \mathrm{Ci})$, with a model-based surface deposition rate along the airflow path as was discussed in the AIB Phase II report, which led to a range of $0.74-3.7 \times 10^{11} \mathrm{~Bq}$ ( 2 to $10 \mathrm{Ci}$ ) potentially released from the drum would have seemed quite reasonable given the $1.78 \times 10^{11} \mathrm{~Bq}(4.81 \mathrm{Ci})$ in the drum. The lower half of the estimated range could be explained with only one drum contributing. The range is only an estimate, after all.

This discussion has relevance because in comparing the total estimated releases to the filter system to the likely source term in Room 7 of Panel 7 based on using the PE-Ci, a health-impact relevant term, the AIB Phase II report concluded that all the attempts made at modeling the source term failed to "conclusively affirm that container 68660 was the sole contributor to the release. Considering the Table 6-12 inventory for all Am and $\mathrm{Pu}$ isotopes of $1.78 \times 10^{11} \mathrm{~Bq}(4.81 \mathrm{Ci})$, a value that sits comfortably in the middle of the projected range, would have allowed a different conclusion.

As previously mentioned, the TAT's estimates of drum 68660's inventory ranged from $2.22-4.07 \times 10^{11} \mathrm{~Bq}(6$ to $11 \mathrm{Ci})$. This range is compatible with the modeling discussed in the AIB report (DOE, 2015a). The TAT concluded this to be an indicator of drum 68660 being the likely sole contributor to the release. However, the TAT's final conclusion that only one drum contributed to the release was based on additional data and visual observations. A unique ${ }^{241} \mathrm{Am} /{ }^{243} \mathrm{Am}$ activity ratio signature $\left(6.46 \times 10^{3}\right)$ was calculated by the TAT for drum 68660, and that ratio was found in ejecta, indicating it came from this drum. This activity ratio is different from comparable ratios for other 
drums in the area of the release. The TAT wrote a very strong conclusion based on all the available data and modeling results:

Therefore, based on the evidence-photography and video; parent drum historical Uranium (U), Pu, and Am data for all LANL material types stored in P7R7; Central Characterization Program (CCP) gamma spectra for key LANL drums in P7R7 using high efficiency neutron counters (HENCs); and $\mathrm{U}, \mathrm{Pu}$, and Am isotopic measurements on post-event samples-it has been concluded that Drum 68660 was the source for the postevent radioactive contamination at the WIPP facility.

\section{Cause of the Drum Breach}

The TAT Report 2015 tested various hypotheses to determine the possible chemical reactions that may have resulted in the failure of the waste drum 68660 and release of material in WIPP. Given the limited access to the breached drum and the absence of extensive sampling and analysis of the contents, the TAT relied on modeling to describe key physical, thermal, and chemical characteristics of the breach of drum 68660. The modeling allowed evaluation of both potential chemical reaction scenarios and the physical aspects of the breach such as pressure-time scenarios that could result in the observed drum breach. Based on the chemical components and physical configuration of the contents of drum 68660 and upon review of chemical literature and results of laboratory testing, the TAT concluded that the contents of drum 68660 were chemically incompatible. The organic ingredients added as sorbents and neutralizers reacted with the nitrate-salt waste and created gases that increased the pressure in the drum. The materials self-heated and combusted. The combination of the nitrate salt residues, organic sorbent (Swheat Scoop ${ }^{\circledR}$ ), and neutralizing agent (TEA) represented a reactive chemical mixture of fuels and oxidizers.

The report further determined that the initiation of the thermal runaway was internal and not caused by phenomena outside drum 68660. The event resulted in chemical reactions and physical changes, both of which accelerated with increased temperature. The TAT and AIB also relied on a photographic examination of the waste in the room where the release occurred. The analysis of the photographic data obtained by “Project Reach" using a specially designed and manufactured 90-foot composite boom equipped with high resolution photographic equipment corroborated that a single drum 
(drum \# 68660) was the source of the February 14 radiological release event at WIPP. There was no causal role played by the February 5 salt haul truck fire.

As discussed in both the Technical Assessment Team (TAT report, 2015) and the Phase II Accident Investigation Board reports (DOE, 2015a), several process errors contributed to the release occurrence. The primary one being that the organization in charge of waste processing: "Did not ensure appropriate SME (subject matter expert) involvement and/or technical evaluation of specification of change to an organic absorbent. In addition, changes to neutralizers also were not sufficiently controlled." The procedure was confusing, specifying "an organic" absorbent, and at the same time giving "zeolite" as an example, an inorganic clay that would not have reacted with the nitrate salts.

\section{Effects of the Radiological Release}

As a result of the radiological event, portions of the WIPP underground primarily along the ventilation path from the location of the incident are contaminated. Comprehensive radiological surveys were performed to determine the extent of the contamination at WIPP underground. Radiological survey results of Panel 7 showed general surface alpha contamination in the range of about 133.3-666.7 Bq in Room 7, about 166.6-333.3 Bq in Room 6 and about 100-466.7 Bq in Room 1 (DOE, 2015a) Figure 1 shows the "contamination distribution" map, which delineates the areas with varying degrees of contamination in the WIPP underground as well as those areas where surface survey work had not been completed at the time the map was produced. Although most of the underground is expected to be free of contamination, the decontamination of affected areas is a key element of the WIPP Recovery Plan.

The decontamination of salt surfaces has not been well documented in the literature. Of the methods tested (dry brushing, vacuum cleaning, water washing (spray misting), strippable coatings, and mechanical grinding), the use of a fresh-water spray has proven to be the most practical and effective approach for reducing surface contamination/re-suspension levels. The water spray dissolves the salt and washes contamination to the floor of the mine. When the salt recrystallizes, it encapsulates the contamination and prevents any resuspension of radioactive particles (Demmer et al., 
2015). In addition to the water spray, in some areas of the underground, WIPP personnel have covered the floor of the mine with brattice cloth and placed a layer of previously mined uncontaminated salt on top of the cloth to further trap any contamination on the floor and to provide a durable surface for vehicle traffic. Additionally, a HEPA vacuum system is used to capture contamination that has not been encapsulated into the salt. Radiological decontamination will not be performed in technically challenging areas like the exhaust shaft (655 vertical meters). When waste emplacement operations resume in the WIPP underground, there will be both clean and contaminated areas. It is envisioned that the initial waste will be emplaced into the contaminated area, e.g., Panel 7 first, followed by emplacement in the drifts between Panels 2 through 4 and 5 through 7 (see Figure 1). Over time, as areas are decontaminated and other contaminated areas are closed off, the majority of operations will take place in the clean parts of the facility.

In addition to the radiological contamination in the WIPP undergound, the smoke from the February 5, fire caused significant soot-damage to mechanical and electrical equipment and systems throughout the underground. Soot was deposited on the mine's walls, shafts, and underground equipment, including the waste hoist and tower, which is used to transport personnel, supplies, and waste containers to the underground for disposal. Soot deposition required a widespread cleanup effort throughout the underground.

\section{Environmental Monitoring Following the Radiation Release Event}

The WIPP underground air sampling results just before (Station A) and after filtration (Station B) are shown in Figure 2. For comparison, the values measured by the separate sampling and analysis program conducted by the WIPP contractor, NWP are also shown. The consistency between the two sampling programs' results reflects the high quality and sensitivity for WIPP's environmental monitoring programs. The values detected at Station A and Station B are considerably higher than those historically measured for these Stations. The analysis of these filters showed how well the HEPA filters performed in trapping underground airborne radioactive particulates. The filter removed the morning after the event at Station A (before exhaust air enters the filters) showed high levels of radioactivity, as expected, about $4337 \mathrm{~Bq} / \mathrm{m}^{3}$ of ${ }^{241} \mathrm{Am}$ and 671

$\mathrm{Bq} / \mathrm{m}^{3}$ of ${ }^{239+240} \mathrm{Pu}$ (Figure 2, Top). The sample collected the very next day showed about 
$342 \mathrm{~Bq} / \mathrm{m}^{3}$ of ${ }^{241} \mathrm{Am}$ and $38.8 \mathrm{~Bq} / \mathrm{m}^{3}$ of ${ }^{239+240} \mathrm{Pu}$. By the morning of February 21, these levels had dropped to $0.2 \mathrm{~Bq} / \mathrm{m}^{3}$ of combined Pu and Am. The sharp spike and subsequent decline in radiation are suggestive of a single release of contamination on February 14. Since the radiological release event, the Station B sampler is the sampler of record for the underground repository ventilation system. The amount of radioactivity measured at Station B (exhaust air after filtration, sampling the amount that was released into the environment) showed much lower levels, about $2.3 \mathrm{~Bq} / \mathrm{m}^{3}$ for ${ }^{241} \mathrm{Am}$ and 0.22 $\mathrm{Bq} / \mathrm{m}^{3}$ for ${ }^{239+240} \mathrm{Pu}$ when it was collected on February 18 at the first collection opportunity, four days after the release (Figure 2, bottom). Given that this particular filter remained in the sampler from the time of the underground radiation detection event until four days after the event, this filter was representative of the total amount of ${ }^{241} \mathrm{Am}$ and ${ }^{239+240} \mathrm{Pu}$, and ${ }^{238} \mathrm{Pu}$ that may have been released into the environment. Three days later a Station B sample was about $0.43 \mathrm{~Bq} / \mathrm{m}^{3}$ for combined Pu and Am. These results show that the filters trapped most of the radioactivity. There never was an amount released that exceeded regulatory limits and there has not been an environmental impact from this event.

As the levels of ${ }^{241} \mathrm{Am}$ and ${ }^{239+240} \mathrm{Pu}$ in the WIPP exhaust air both before and after the filtration continued to remain low beginning April 22, 2014, daily filter analysis was discontinued and a weekly composite filter for the CEMRC and monthly composite filter for the NWP began to be used for the determination of actinides. The monthly composite filter samples results from Station A and Station B are summarized in Supplementary material Tables S1 and S2. As shown in Tables S1 and S2, trace amounts of ${ }^{241} \mathrm{Am}$ and ${ }^{239+240} \mathrm{Pu}$ are still measurable above MDC (minimum detectable concentration) in these filters. Again, these levels are very low and are not expected to cause any adverse health or environmental consequences.

Figure 3 shows a time-series of ${ }^{239+240} \mathrm{Pu}$ and ${ }^{241} \mathrm{Am}$ activity concentration measured in unfiltered underground air (Station A) by CEMRC (Figure 3, Top) as well as by NWP (Figure 3, Bottom) in the period from 1999 to the end of 2013. The historical data collected by both monitoring organizations showed that from 2000 through 2013 only nine Station A measurements can be declared as a certain detection of a radionuclide. Detectable concentrations of Pu isotopes $\left({ }^{239+240} \mathrm{Pu}\right.$, or $\left.{ }^{238} \mathrm{Pu}\right)$ and ${ }^{241} \mathrm{Am}$ 
only occurred in four monthly composite samples from 2003, 2008, 2009 and 2010 (CEMRC report, 2011). Since ${ }^{238} \mathrm{Pu}$ and ${ }^{239+240} \mathrm{Pu}$ concentrations in the WIPP exhaust air were above detection limits in only two of the monthly composite samples (February 2008 and April 2009), the activity ratios between ${ }^{238} \mathrm{Pu}$ and ${ }^{239+240} \mathrm{Pu}$ were calculated for those two occurrences. The February 2008 sample ratio was 0.039 and the April 2009 sample ratio was 0.023 . A mean ${ }^{238} \mathrm{Pu} /{ }^{239+240} \mathrm{Pu}$ activity ratio of $0.025 \pm 0.004$, with a range from 0.019-0.039 is compatible with a global fallout origin as reported in different studies. This compatibility with the two measured ratios from WIPP is not proof that there was not a trace of ${ }^{238} \mathrm{Pu}$ released from within the repository; it is only suggestive of a global fallout origin. There was no unambiguous evidence of releases from WIPP operations until the February 14, 2014 event.

The pre- and post-release concentrations of ${ }^{241} \mathrm{Am}$ and ${ }^{239+240} \mathrm{Pu}$ measured in the filter samples collected from Station B are shown in Figure 4. The pre-release concentrations of ${ }^{241} \mathrm{Am}$ and ${ }^{239+240} \mathrm{Pu}$ were all below the MDC. Since CEMRC was not doing Station B analysis before the events, the pre-release Station B data were taken from NWP (ASER Report, 2014). It should be noted that quarterly composite samples were used from 1999 until 2013 by the NWP for determination of actinides.

Intensified ambient air sampling analyses were also performed in and around the WIPP site to ascertain whether or not there were releases to the ground surface following the radiation release event from the WIPP underground. Trace levels of ${ }^{241} \mathrm{Am}$ and ${ }^{239+240}$ $\mathrm{Pu}$ were briefly detected at a monitoring station (Near Field Stations) located approximately one $\mathrm{km}$ ( 0.6 miles) northwest of the WIPP facility. The filter that was analyzed had been installed at the station prior to the event, on Tuesday, February 11, 2014 and was removed on Sunday, February 16, 2014. The levels detected $\left(81.4 \mu \mathrm{Bq} / \mathrm{m}^{3}\right.$ of ${ }^{241} \mathrm{Am}$ and $5.8 \mu \mathrm{Bq} / \mathrm{m}^{3}$ of ${ }^{239+240} \mathrm{Pu}$ ) at this sampling station indicated a small release of radioactive particulate from the WIPP site.

A second ambient air sampling station (Cactus Flats Station) located approximately $19 \mathrm{~km}$ southeast of the WIPP facility on highway 128 showed no detection of radioactive particles. Although the values measured were above the pre-release background levels, it is important to note that the levels detected were very low and well 
below any level of public health or environmental concern. There is no risk to anyone from contamination levels this low.

The monitoring results of a third ambient air sampling station located $91 \mathrm{~m}$ from the underground air exhaust point (Onsite station) and within the WIPP property protection area were not accessible for a few days after the release event. That filter was collected Tuesday, February, 18, 2014. This Onsite filter showed $115.2 \mu \mathrm{Bq} / \mathrm{m}^{3}(1.3$ $\mathrm{Bq} / \mathrm{sample})$ of ${ }^{241} \mathrm{Am}$ and $10.2 \mu \mathrm{Bq} / \mathrm{m}^{3}(0.11 \mathrm{~Bq} / \mathrm{sample})$ of ${ }^{239+240} \mathrm{Pu}$, again not posing any health risk concern. A week after the event, the airborne radioactive particulate levels at these stations had decreased by a hundred times, and two weeks later the levels at these stations were back to the pre-release levels and sometimes not even detectable, demonstrating no long-term environmental contamination. Following the radiation release event, the CEMRC added three additional high-volume sampling stations in order to provide additional information to area residents in the event of a future radiation release event. The new sampling stations are located at: (1) Carlsbad (behind the CEMRC facility), (2) south side of Loving and (3) east side of the WIPP facility. The levels of ${ }^{241} \mathrm{Am}$ and ${ }^{239+240} \mathrm{Pu}$ in these stations are consistent with the normal background levels usually measured in the WIPP vicinity. The levels of ${ }^{239+240} \mathrm{Pu}$ and ${ }^{241} \mathrm{Am}$ concentrations in ambient air around the WIPP vicinity both before and after the February 14 radiation release event analyzed by CEMRC are shown in Figure 5.

The weekly ambient air samples collected by NWP also detected trace levels of ${ }^{241} \mathrm{Am}$ and ${ }^{239+240} \mathrm{Pu}$ at four sampling locations (ASER, 2014). The levels of these radionuclides above MDC were detected only twice. The highest concentrations measured were $15800 \mu \mathrm{Bq} / \mathrm{m}^{3}(0.813 \mathrm{~Bq} / \mathrm{sample})$ for ${ }^{241} \mathrm{Am}$ and $1190 \mu \mathrm{Bq} / \mathrm{m}^{3}(0.0612$ Bq/sample) for ${ }^{239+240} \mathrm{Pu}$ Bq/sample) detected on February 15, 2014 at WIPP Far Field (WFF) sampling station. A higher than background levels of ${ }^{241} \mathrm{Am}$ was also measured at the WEE, WSS and SMR monitoring stations. The levels measured were $45.7 \mu \mathrm{Bq} / \mathrm{m}^{3}$ (0.0095 Bq/sample) at WEE and $11.3 \mu \mathrm{Bq} / \mathrm{m}^{3}$ (0.0024 Bq/sample) at WSS both detected on February 15, 2014. The other detection of ${ }^{241} \mathrm{Am}$ was at the SMR monitoring station, which had $14.9 \mu \mathrm{Bq} / \mathrm{m}^{3}$ (0.0041 Bq/sample) of ${ }^{241}$ Am detected on February 18, 2014. At the time this article was prepared, measured levels at all sampling locations are below the MDC. The pre- and post-release concentrations of ${ }^{241} \mathrm{Am}$ and ${ }^{239+240} \mathrm{Pu}$ measured in 
ambient air by NWP in the vicinity of the WIPP site are shown in supplementary material Figure S3.

The WIPP's historical ambient air monitoring data indicate frequent detection of ${ }^{239+240} \mathrm{Pu}$ and ${ }^{241} \mathrm{Am}$ in ambient air samples collected around WIPP. The source of preevent airborne contamination is largely wind suspension of weapons-testing contamination present on soils (Arimoto et al., 2002, Arimoto et al., 2005). That is ambient contamination from atmospheric weapons testing conducted in the 1950s and 1960s, and not attributable to the presence of WIPP. During most years studied, the peaks in ${ }^{239+240} \mathrm{Pu}$ and ${ }^{241} \mathrm{Am}$ activities generally occur in the March to June time-frame, which is when strong and gusty winds in the area frequently give rise to blowing dust. Arimoto et al., 2002, Stout and Arimoto, 2010 have shown that in semi-arid conditions like at WIPP, the plutonium-bearing aerosols tend to increase in environmental air samples with winds of $4 \mathrm{~ms}^{-1}$ with a maximum at wind speeds of $7 \mathrm{~ms}^{-1}$ and staying constant at wind speeds above $7 \mathrm{~ms}^{-1}$. These aerosol particles are then readily trapped on a filter in an air monitoring station, leading to their frequent detections during high wind events.

In the Carlsbad area, where WIPP is located, there is an additional potential local source of anthropogenic radioactivity from an underground nuclear test that was part of the Plowshare project, the Gnome test (USAEC, 1963). The Gnome site is located only 5.5 miles $(8.8 \mathrm{~km})$ southwest of the WIPP site. In 1961 an underground test of a 3.3kiloton ${ }^{239} \mathrm{Pu}$ device vented radioactive materials to the environment (Faller, 1994). The Gnome plume reportedly traveled mostly north-north-west not too far from the WIPP site. The site was decontaminated several times since that time. However, low levels of ${ }^{137} \mathrm{Cs}$ and plutonium are still detectable in some surface soil samples from the Gnome site. The transport of these contaminants from the Gnome site to the WIPP remains a possibility during high wind seasons. However, more than fifteen years of monitoring data and the activity levels detected, as well as their atomic ratio measurements, suggest that pre-release-event plutonium and americium in aerosol and soil samples mainly represent redistributed global fallout.

\section{Detection of Minor Radionuclides}

To a lesser extent, isotopes of ${ }^{238} \mathrm{Pu},{ }^{228} \mathrm{Th},{ }^{234} \mathrm{U}$, and ${ }^{137} \mathrm{Cs}$ were also detected in the WIPP underground air samples. However, these isotopes were not as consistently 
detected as ${ }^{241} \mathrm{Am}$ and ${ }^{239+240} \mathrm{Pu}$. For example, the ${ }^{137} \mathrm{Cs}$ was detected only once at a Station A filter $\left(0.0049 \mathrm{~Bq} / \mathrm{m}^{3}\right)$, but was not detected in any of the post-filter air collected from Station B. The detection of ${ }^{238} \mathrm{Pu}$ persisted for about a week. The highest levels of ${ }^{238} \mathrm{Pu}$ detected were $30.3 \mathrm{~Bq} / \mathrm{m}^{3}$ at Station A (pre-filtration) and $0.03 \mathrm{~Bq} / \mathrm{m}^{3}$ at Station B (post-filtration). These levels were measured on filters collected on February 14, 2014. Similarly, the highest levels of isotopes of thorium and uranium were measured on those same filter samples. These results show that the filter system trapped most of the radioactivity. There never was an amount released that exceeded regulatory limits, and there is no reason to suspect there will be any environmental impact from this minor external release event.

\section{Source Term Estimation}

To assess the magnitude of the accident and potential radiological doses received by the general populations, it is important to estimate the source term of the radiological release into the environment. Since the air in the repository exits to the surface through the exhaust shaft, this shaft is the sole potential pathway for airborne radioactivity release from the WIPP during the operational phase. So, in the source term estimation, the station $\mathrm{B}$ airborne concentration data for $\mathrm{Am}$ and $\mathrm{Pu}$ isotopes was used. Summing all isotopes ( $\mathrm{Pu}$ and $\mathrm{Am}$ ) measured over the first week after the event, and taking into account the total air flow through the filters as $1699 \mathrm{~m}^{3}$ per minute and that the station B air sampler draws $0.06 \mathrm{~m}^{3}$ per minute, the source term based on CEMRC data was estimated as $2.53 \times 10^{7} \mathrm{~Bq}$ of ${ }^{241} \mathrm{Am}, 3.06 \times 10^{6} \mathrm{~Bq}$ of ${ }^{241} \mathrm{Pu}$ and $2.48 \times 10^{6} \mathrm{~Bq}$ of ${ }^{239+240} \mathrm{Pu}$, summing to a total release of $3.08 \times 10^{7} \mathrm{~Bq}(\sim 0.83 \mathrm{mCi})$. The total estimated release based on NWP analyses of the station B filters (ASER report, 2014) was calculated as $4.51 \times 10^{7} \mathrm{~Bq}$ of ${ }^{241} \mathrm{Am}, 2.94 \times 10^{6}$ of ${ }^{241} \mathrm{Pu}$, and $2.52 \times 10^{6} \mathrm{~Bq}$ of ${ }^{239+240} \mathrm{Pu}$, suggesting a total release of $5.06 \times 10^{7}(\sim 1.3 \mathrm{mCi})$. The difference is ${ }^{241} \mathrm{Am}$ source term between NWP and CEMRC is probably because NWP extrapolated data from gross alpha values. This source term is dominated by ${ }^{241} \mathrm{Am}(>90 \%)$. Without further information, it is difficult to determine which of these analyses is to be preferred.

Furthermore, the Station A airborne concentration data for Am and Pu isotopes was used to estimate the source term of the radiological release into the WIPP underground. Based on CEMRC data, the source term of the radiological release into the 
WIPP underground was estimated as $6.66 \times 10^{9} \mathrm{~Bq}$ of ${ }^{241} \mathrm{Am}, 2.90 \times 10^{8} \mathrm{~Bq}$ of ${ }^{241} \mathrm{Pu}$ and $1.49 \times 10^{9} \mathrm{~Bq}$ of ${ }^{239+240} \mathrm{Pu}$, summing to a total release of $8.44 \times 10^{9} \mathrm{~Bq}(\sim 228 \mathrm{mCi})$. The total estimated release based on NWP analyses of the Station A filters (DOE report 2015a) was calculated as $4.56 \times 10^{9} \mathrm{~Bq}$ of ${ }^{241} \mathrm{Am}, 2.26 \times 10^{8} \mathrm{~Bq}$ of ${ }^{241} \mathrm{Pu}$, and $1.45 \times 10^{9} \mathrm{~Bq}$ of ${ }^{239+240} \mathrm{Pu}$, suggesting a total release of $6.23 \times 10^{9} \mathrm{~Bq}(\sim 168 \mathrm{mCi})$. As noted before, without further information, it is difficult to determine which of these analyses is to be preferred.

\section{Bioassay results of the WIPP workers}

Bioassays were performed by NWP on personnel who were at the site the night of the radiation release event and the day after to determine if there was any internal uptake of airborne contamination from the event. There were 11 employees on the night shift at the time of the release and two additional employees entered the site in response to the accident. No employees were underground when the release occurred. All 13 employees present the night of the event were checked for any external contamination before being allowed to leave the site (DOE, 2014b). Bioassay samples were collected from these 13 employees to determine their possible exposure from inhaling airborne radioactive particles. The morning after the accident, 140 employees returned to the site unaware that radiation had been detected on the surface. These workers were instructed to shelter in place later that morning, after a radiation release was confirmed. All these 140 employees were also offered bioassay analysis to ensure their health and safety (DOE, 2014b).

For the purpose of dosimetry monitoring, these employees were grouped into four categories based on the potential for exposure. These groups are (1) highest potential for exposure (14 personnel); (2) elevated potential for exposure (21 personnel); (3) remaining personnel at the WIPP site during the release period (118 total) and (4) personnel not at WIPP site during the release period but volunteered to participate (26 personnel). In total, 140 urine and 31 fecal samples were analyzed. Initial bioassay results showed one positive urine and 21 positive fecal samples for low levels of ${ }^{239+240} \mathrm{Pu}$ and ${ }^{241} \mathrm{Am}$. The highest activity detected was $0.024 \mathrm{~Bq} / \mathrm{sample}$. Follow-up testing of biological samples taken from the 13 employees who were at the WIPP site during the event were all below detection limits for plutonium and americium, the two radionuclides that were detected in preliminary bioassay samples. In vivo radio-bioassay measurements 
(whole-body counting and lung/chest counting) were also performed on all these employees. All had negative chest counts, indicating they had no detectable radioactive contamination deep in their lungs.

\section{Dose to the WIPP workers and the local public}

The radionuclides present in the environment can give both internal and external doses. Internal dose is caused by the intake of radionuclides in humans. Prior to the radiation release event at WIPP, the only radiation dose received by the general public living in the vicinity of the WIPP site has been that associated with background radiation. The major routes of intake of radionuclides in the general public are ingestion and inhalation. Following the release event, the air concentration data collected during the first week of the accident were utilized to estimate the potential dose received by workers and the nearby public. The particles were conservatively assumed to be in the respirable range of 0.1 to 10 microns. Although the release was determined to be mostly Am and some $\mathrm{Pu}, 100 \% \mathrm{Pu}$ was assumed because it has a higher ICRP 60 (International Commission on Radiological Protection) dose conversion factor and would result in a more conservative dose estimate. The ICRP has stated that the initial dose action levels for emergency exposure situations should be set in the range of 20-100 $\mathrm{mSv}$ to the public and that projected doses approaching $100 \mathrm{mSv}$ will almost always justify protective measures (ICRP, 2008).

Dose assessment modeling (Figure 6) from the release data showed a potential dose of greater than $10 \mathrm{mrem}(0.1 \mathrm{mSv})$ at the site boundary (within $0.1 \mathrm{~km}$ of the WIPP), 1-10 mrem (0.01-0.1 mSv) at the WIPP far Field (1.4 km NW of the WIPP) and about 0.1-1 mrem (0.001 -0.01 mSv) at location $5 \mathrm{~km}$ from the WIPP (Robert Hayes, 2014). There are no nearby cities or settlements in the WIPP vicinity; there is one ranch nearby, at the property-protection site boundary, with a house that is not occupied fulltime. According to the dose modeling performed, the nearest rancher would have received $0.0002 \mathrm{mSv}$ of a lifetime exposure from the WIPP release ((Robert Hayes, 2014).

The internal doses of the 21 personnel, who were exposed to low levels of radiation by the release event of February 14, were also evaluated based on the initial bioassay measurements. Figure 7 illustrates the calculated dose received by 
21contaminated WIPP workers because of the WIPP radiation release event. The highest maximum dose received by WIPP worker was $8 \mathrm{mrem}(0.8 \mathrm{mSv})$, which is less than the annual permissible dose for nuclear workers. So, the risk of any radiation induced health effects on workers would be very small, approaching zero.

As a comparison, the annual natural radiation dose at the elevation of WIPP (about 1,000 meters above sea level) is around $310 \mathrm{mrem}(3.10 \mathrm{mSv})$. Natural radiation sources include soil and rocks, certain building materials, cosmic rays, some foods, radon and radiation sources in our bodies and plants. The DOE and international radiation protection organizations recommend that nuclear activities not add more than a $1 \mathrm{mSv}$ annual maximum additional dose for the general public and a 5 mrem $(0.05 \mathrm{~Sv})$ annual maximum additional dose limit from the same activity for radiation workers. The average person living in the United States receives an annual dose of about 620 mrem $(6.2 \mathrm{mSv})$ from exposure to naturally occurring and medical sources of radiation.

\section{Activity and the mass ratios of the materials released from the WIPP}

The activity and mass ratios of radionuclides vary according to the source, so they can act as a fingerprint to identify the origin of the plutonium from different sources released into the environment. The radiological analyses conducted on a variety of sample media collected by the CEMRC, NWP and the TAT samples from the immediate vicinity of the breached drum in Room 7 of Panel 7 were examined to determine the isotope ratios of the radioactive materials released from the breached drum. Sample media studied were: (1) the WIPP underground air filter samples from Station A and Station B collected by CEMRC and NWP, (2) the post event analysis of underground CAM-151 filters, (3) the air sampled from Fixed Air sampler, FAS-118, which sampled the airborne activity at the inlet to Panel 7, upstream of CAM-151, (4) the surface swipes and smear samples collected from the event area and (5) the debris ejected from the breached drum. The isotopic ratio of key nuclides measured across the breached drum and the various sample media are listed in Table 1. Early post-event analysis of Station A showed ${ }^{241} \mathrm{Am} /{ }^{239+240} \mathrm{Pu}$ ratio varied between 4.81 and 20.67 on separate days during the progression of the event, while the corresponding ratio at Station B varied in the range 2.95 to 16.26 , but the average ratios at both the Stations remained relatively constant, around 10 , even though the data showed a relatively wide range. A similar variation in 
${ }^{241} \mathrm{Am} /{ }^{239} \mathrm{Pu}$ activity ratio was also observed in the early post-event filter samples collected from Station A and Station B by NWP (Table 1). The ${ }^{241} \mathrm{Am} /{ }^{239} \mathrm{Pu}$ ratios in their samples were shown to vary from 1.63 to 27.62 at Station A and from 5.13 to 18.03 at Station B during the course of the event, but the average ratios remain fairly constant, about 10 at both the Stations.

The post event analysis of underground CAM-151 filters measured by Savannah River National Laboratory (SRNL) showed ${ }^{241} \mathrm{Am} /{ }^{239} \mathrm{Pu}$ ratios in the range 12.1 to 22.2 and the FAS-118 filter had ${ }^{241} \mathrm{Am} /{ }^{239} \mathrm{Pu}$ activity ratios of 26.3 (Table 1). The contamination on the FAS-118 filter was likely due to a momentary back-pulse of airflow during the ventilation change and/or release of materials into the air flow. These results are very similar to the ratios measured in Station A and Station B for the same period.

By contrast, the ${ }^{241} \mathrm{Am} /{ }^{239} \mathrm{Pu}$ ratios measured in swipes, smear and debris ejected from the breached drum were significantly lower than those measured on CAM-151, FAS-118, Station A and Station B. For example, the ${ }^{241} \mathrm{Am} /{ }^{239} \mathrm{Pu}$ activity ratio in the swipe samples collected from Panel 7 were in the range of 9.0-10.2, while those of debris samples from panel $7 \mathrm{had}{ }^{241} \mathrm{Am} /{ }^{239} \mathrm{Pu}$ ratios in the range 1.94-5.15 with a mean value of 5.24 (Table 1). These values agree with the ${ }^{241} \mathrm{Am} /{ }^{239} \mathrm{Pu}$ activity ratio of 4.75 estimated for the bulk contents of the breached drum. The ${ }^{241} \mathrm{Am} /{ }^{239} \mathrm{Pu}$ activity ratio analyses conducted on a variety of sampled media following the radiation release event reveals that the lowest ratios were measured closest to the source and the ratio increases with distance from the source (Table 1). This deviation in ratios can be attributed to the potential fractionation of the ${ }^{241} \mathrm{Am}$ and ${ }^{239} \mathrm{Pu}$ isotopes during the event and the airborne transport through the WIPP facility and out via the ventilation system. Given the different chemical and physical properties of the two elements, such fractionation is to be expected.

Additionally, the process (anion exchange or oxalate precipitation) used to produce the waste salts is also a contributing factor in the difference in ratios between the bulk contents of the drum and the material ejected. When an anion-exchange process is used to recover plutonium materials, the liquid effluent contains most of the Am. When that liquid effluent is run through the evaporation process, it produces salt with high $\mathrm{Am} / \mathrm{Pu}$ ratios. When an oxalate precipitation process is used, plutonium is precipitated with oxalic acid post ion-exchange. The filtrate from the oxalate precipitation step is therefore 
very low in Am and when these liquids go through the evaporation process the resultant salt has a low Am/Pu ratio (TAT report, 2015).

Unlike the ${ }^{241} \mathrm{Am} /{ }^{239} \mathrm{Pu}$ ratio which varied substantially across the breached drum and the various media samples, the ratios between the radionuclides of the identical element such as ${ }^{241} \mathrm{Am} /{ }^{243} \mathrm{Am}$ or ${ }^{240} \mathrm{Pu} /{ }^{239} \mathrm{Pu}$ remain fairly constant, and are likely better indicators of radioactive materials released from the WIPP. The breached drum had ${ }^{241} \mathrm{Am} /{ }^{243} \mathrm{Am}$ activity ratios of $6.46 \times 10^{3}$. The ${ }^{241} \mathrm{Am} /{ }^{243} \mathrm{Am}$ activity ratios measured in the CAM filters were $8.90 \times 10^{3}, 8.93 \times 10^{3}$ and $9.43 \times 10^{3}$ (Avg. $9.10 \times 10^{3}$ ). A similar ${ }^{241} \mathrm{Am} /{ }^{243} \mathrm{Am}$ activity ratio $\left(8.10 \times 10^{3}\right)$ was also found in the FAS-118 filter (DOE, 2015a).

The ${ }^{238} \mathrm{Pu} /{ }^{239+240} \mathrm{Pu}$ activity ratio at Station A and Station B also remained fairly consistent during the course of the event. The data collected by CEMRC from Station A showed ${ }^{238} \mathrm{Pu} /{ }^{239+240} \mathrm{Pu}$ activity ratios varied between $0.03-0.10$ with a mean value of 0.05, while the corresponding ratios at Station B varied between 0.028-0.214 with a mean value of 0.053 . Furthermore, analyses of filter samples collected by NWP showed a mean ${ }^{238} \mathrm{Pu} /{ }^{239} \mathrm{Pu}$ activity ratio of 0.048 (range $0.003-0.080$ ) at Station A and 0.050 (range 0.003-0.273) at Station B, which is in good agreement with the values estimated for the bulk content of the breached drum $\left({ }^{238} \mathrm{Pu} /{ }^{239} \mathrm{Pu}\right.$ activity ratio of 0.045 and ${ }^{238} \mathrm{Pu} /{ }^{239+240} \mathrm{Pu}$ activity ratio of 0.037$)$.

Fairly consistent ${ }^{241} \mathrm{Am} /{ }^{243} \mathrm{Am}$ and ${ }^{240} \mathrm{Pu} /{ }^{239} \mathrm{Pu}$ atom ratios were also found in the debris and swipe samples taken from Room 7 of Panel 7 following the radiation release event. The ${ }^{241} \mathrm{Am} /{ }^{243} \mathrm{Am}$ mass ratios measured in the CAM filters were found to be in the range 461-505; in the debris samples from Panel 7, the ratios measured were in the range 411-501; in the swipe samples collected from the same location, the ratios were found to be in the range 409-455 (DOE, 2015a). These values are close to the ${ }^{241} \mathrm{Am} /{ }^{243} \mathrm{Am}$ mass ratio of $479 \pm 90$ reported for the breached drum (DOE, 2015a).

The ${ }^{240} \mathrm{Pu} /{ }^{239} \mathrm{Pu}$ mass ratios measured were $0.0720-0.0770$ in the CAM filters, averaged 0.0752 in the swipes and 0.0777 in the debris collected from Panel 7 (DOE, 2015a).

Given the variability in the historical processing and post-event measured ${ }^{241} \mathrm{Am} /{ }^{239} \mathrm{Pu}$ ratios, we recommend that although in a general sense the $\mathrm{Am} / \mathrm{Pu}$ signature could be used to distinguish radioactive materials released from this particular WIPP 
accident, the ${ }^{240} \mathrm{Pu} /{ }^{239} \mathrm{Pu}$ and ${ }^{241} \mathrm{Am} /{ }^{243} \mathrm{Am}$ ratios are much more reliable signatures being the two dominant elements in the waste stream involved in this release event. This waste stream, however, is not typical in terms of the isotopic composition of the various waste streams being disposed of in the WIPP repository. Isotopes of the same elements will behave similarly, both chemically and physically, and therefore obviate any variability due to fractionation.

\section{Communication of Results and Public Involvement}

The release of any radioactivity has the potential to alarm portions of the general population who do not understand the difference between actual risk and perceived risk. It is not suprising that some media treatments of the WIPP radiation release event amplified the public's perception of their risk. Following the event, there were rumors propagated in some media concerning evacuations planned or in progress, which did not help assure the public. The WIPP release incident was newsworthy, but it was not dangerous to any member of the public. To eliminate unnecessary concern surrounding fear of radiation, the monitoring data were posted on the CEMRC website as they were reviewed and verified. Graphs of the monitoring data were displayed along with information on how to interpret the graphs in order to show the decreasing trend in radiation in the ambient air with time. Information on the contaminant levels that might have been a cause for public concern, had they been found, was also posted.

Throughout the duration of the response to the February 14 release event, "town hall" meetings were held with members of the public to identify and discuss their concerns about the WIPP radiation release event. This timely dissemination of information provided the public a key element of trust and transparency. Public access to the monitoring data and their ability to directly participate in CEMRC's whole body counting provided a sense of security to concerned citizens after the event in evaluating their own safety, which has a direct relationship to their continuing acceptance of a nearby nuclear facility.

\section{Path forward for the WIPP}

The recovery and resumption of TRU waste disposal operations at WIPP are crucial to the DOE's national Cold War legacy clean-up mission. After months of investigations into the cause of a truck fire and a radiological release, the DOE released a 
recovery plan at the end of September, 2014 (DOE, 2015b) that outlines the steps necessary to clean up and to resume limited waste emplacement operations by late 2016 . Part of the recovery plan included initial closure of Panel 6 and Panel 7, Room 7. These two locations of "suspect waste" drums have been isolated from underground air circulation using run of mine salt and chain link/brattice cloth barriers behind steel doors as initial closure structures.

Another key element of the recovery plan is to increase the ventilation capacity. Increasing ventilation capacity is a principal requirement for safe underground operations, as it supports worker safety, mining, and waste emplacement. Since the radiation release event, the WIPP ventilation system has been operating in filtration mode and will continue to be operated in this configuration. In filtration mode, underground airflow is reduced to $28 \mathrm{~m}^{3} / \mathrm{s}$, which is inadequate to support the recovery of WIPP and resume waste emplacement and, eventually, full disposal operations and concurrent mining operations. Standard WIPP underground operations ran at approximately 200 $\mathrm{m}^{3} / \mathrm{s}$ of airflow. There has been progress on the interim ventilation system, which will increase the overall amount of airflow in the underground facility to $54 \mathrm{~m}^{3} / \mathrm{s}$. A new permanent ventilation system is being designed to provide $\sim 198 \mathrm{~m}^{3} / \mathrm{s}$ air flow. The addition of new permanent ventilation system will enable the WIPP underground operations back to return to full operation, unrestricted by ventilation rates.

Another key operation that has been resumed is roof bolting operations, a process necessary in order to secure the walls and access routes in the underground facility. Recovery activities such as decontamination of selected underground areas, safety inspections of underground electrical equipment, cleaning and decontaminating underground vehicles, and re-establishing underground habitability to meet worker safety and health standards are nearing completion, and planning for operational readiness reviews is underway.

\section{Conclusion}

After almost fifteen years of successful waste disposal operations, the WIPP repository had its first accidental release event on February 14, 2014. It was the first unambiguous release at the WIPP. The accident released moderate levels of radioactivity into the underground air. A small portion of the contaminated underground air also 
escaped to the surface through imperfectly sealing dampers and was detected approximately one kilometer away from the facility.

According to source-term estimates, the actual amount of radioactivity released from the WIPP site was less than 1.5 millicurie. The dominant radionuclides released were americium and plutonium, in a ratio that matches the content of the breached drum. The highest activities detected outside were $115.2 \mu \mathrm{Bq} / \mathrm{m}^{3}$ for ${ }^{241} \mathrm{Am}$ and $10.2 \mu \mathrm{Bq} / \mathrm{m}^{3}$ for ${ }^{239+240} \mathrm{Pu}$ at a sampling station located 91 meters away from the underground air exhaust point and $81.4 \mu \mathrm{Bq} / \mathrm{m}^{3}$ of ${ }^{241} \mathrm{Am}$ and $5.8 \mu \mathrm{Bq} / \mathrm{m}^{3}$ of ${ }^{239+240} \mathrm{Pu}$ at a monitoring station located approximately one kilometer northwest of the WIPP facility. The levels detected were very low and localized, and no radiation-related health effects among local workers or the public would be expected. Soil, water, vegetation and animal sampling found no enhanced levels of the actinides of interest.

A week after the event, the airborne radioactive particulate levels at these stations had decreased by a hundred times, and two weeks later the levels at these stations were back to the pre-release levels and sometimes not even detectable, demonstrating no longterm environmental contamination. In terms of radiological risk at or in the vicinity of the WIPP site, the increased risk from the WIPP releases is exceedingly small, approaching zero.

\section{Acknowledgement}

This research is supported by grant from US Department of Energy, Carlsbad Field Office of DOE through Grant No. DE-EM 0002423. We thank the scientists and staff of CEMRC for their many contributions to this project. Any opinions, findings and conclusions or recommendations expressed in this material are those of the authors and do not necessarily reflect the views of the sponsors. 


\section{References}

Application of the Commission's recommendations for the protection of people in emergency exposure situations: ICRP publication 109. Ann ICRP. 2008; 39:1-73.

Arimoto R, Kirchner T, Webb J.L, Conley M, Stewart B, Schoep D, Walthall M. ${ }^{239,240}$ Pu and inorganic substances in aerosols from the vicinity of the Waste Isolation Pilot Plant: the importance of re-suspension. Health Phys. 2002; 83:456-470.

Arimoto, R.; Webb, J.L.; Conley, M. Radioactive contamination of atmospheric dust over southeastern New Mexico. Atom. Environ. 2005; 39: 4745-4754.

Carlsbad Environmental Monitoring \& Research Center (CEMRC). www.cemrc.org

Carlsbad Environmental Monitoring \& Research Center (CEMRC) Annual Report, 2011. http://cemrc.org/reports/11rept/index.html. New Mexico State University. Carlsbad, NM.

Demmer R, Reese S, Nelson R, Van Luik A. 2015, Using Water to Decontaminate Rock Salt at the Waste Isolation Pilot Plant, New Mexico, USA, Migration 2015, September 13-18, Santa Fe, New Mexico.

DOE, 2014a. U.S. Department of Energy- Accident Investigation Board (AIB) Report, Underground Salt Haul Truck Fire at the Waste Isolation Pilot Plant, February 5, 2014. Washington, DC: U.S. Department of Energy. Accessible at: http://www.wipp.energy.gov/Special/AIB\%20Report.pdf

DOE, 2014b. U.S. Department of Energy Accident Investigation Report, Phase-I. Radiological Release Event at the Waste Isolation Pilot Plant on February 14, 2014. Washington, DC: U.S. Department of Energy. Accessible at: http://www.wipp.energy.gov/Special/AIB_Final_WIPP_Rad_Release_Phase1_04_22_20 $\underline{14 . p d f}$

DOE, 2015a. U.S. Department of Energy Accident Investigation Report, Phase -II. Radiological Release Event at the Waste Isolation Pilot Plant on February 14, 2014. Washington, DC: U.S. Department of Energy. Accessible at:http://www.wipp.energy.gov/Special/AIB_WIPP\%20Rad_Event\%20Report_Phase $\% 2$ OII.pdf

DOE, 2015b. U.S. Department of Energy, WIPP Waste Isolation Pilot Plant Recovery web site, accessed 09-29-2015, http://www.wipp.energy.gov/Special/Station\%20B.pdf 
Faller F. Residual soil radioactivity at the Gnome Test Site in Eddy County, New Mexico, Report No. EPA 600/R-94/117, July 1994. Washington, DC, Environmental Protection Agency.

Robert Hayes. February $14^{\text {th }}$, contamination release consequence assessment. Rev. 1," 8 March 2014, Nuclear Waste Partnership, available online at:

http://www.wipp.energy.gov/Special/Modeling\%20Results.pdf

Stout J.E, Arimoto R. Threshold wind velocities for sand movement in the Mescalero Sands of southeastern New Mexico, J. of Arid Environ. 2010; 74:1456-1460.

TAT-Report: Waste Isolation Pilot Plant Technical Assessment Team Report, March, 2015.http://www.wipp.energy.gov/Special/TECHNICAL_ASSESSMENT_TEAM_REP ORT.pdf

USAEC. Gnome/Coach site disposal options. U.S. Atomic Energy Commission NVO131. 1963. Las Vegas, NV.

Waste Isolation Pilot Plant Annual Site Environmental Report (ASER) for 2011. DOE/WIPP-12-3489, U.S. Department of Energy. Accessible at: http://www.wipp.energy.gov/information_repository/cra/CRA2014/References/Others/US_DOE_2012_WIPP_Annual_Site_Environmental_Report_20 11_DOE_WIPP_12_3489.pdf

Waste Isolation Pilot Plant Annual Site Environmental Report (ASER) for 2014. DOE/WIPP-15-8866, Washington, D.C., U.S. Department of Energy. Accessible at: www.wipp.energy.gov/library/ser/DOE-WIPP-15-8866 ASER 2014.pdf 
Table 1. Isotopic ratios of the radioactive materials released from the WIPP

\begin{tabular}{|c|c|c|c|c|c|c|}
\hline Sample type & $\begin{array}{l}{ }^{241} \mathrm{Am} /{ }^{239} \mathrm{Pu} \\
\text { Activity ratio }\end{array}$ & $\begin{array}{l}{ }^{241} \mathrm{Pu} /{ }^{239+240} \mathrm{Pu} \\
\text { Activity ratio }\end{array}$ & $\begin{array}{r}{ }^{241} \mathrm{Am} /{ }^{243} \mathrm{Am} \\
\text { Activity ratio }\end{array}$ & $\begin{array}{l}{ }^{238} \mathrm{Pu} /{ }^{239+240} \mathrm{Pu} \\
\text { Activity ratio }\end{array}$ & $\begin{array}{l}{ }^{240} \mathrm{Pu} /{ }^{239} \mathrm{Pu} \\
\text { mass ratio }\end{array}$ & $\begin{array}{c}{ }^{241} \mathrm{Am} /{ }^{243} \mathrm{Am} \\
\text { mass ratio }\end{array}$ \\
\hline Breached drum & 4.75 & 3.42 & $6.46 \mathrm{E}+03$ & 0.045 & 0.073 & $479 \pm 90$ \\
\hline Panel 7, debris & $\begin{array}{c}5.24 \\
(4.68-5.95)\end{array}$ & - & - & - & 0.075 & $\begin{array}{c}455 \\
(411-501)\end{array}$ \\
\hline Panel 7,smears & $1.95-5.15$ & - & - & & 0.078 & $467-472$ \\
\hline Panel 7, swipes & $9.0-10.2$ & - & - & - & - & - \\
\hline $\begin{array}{l}\text { CAM filters } \\
(\mathrm{n}=8)\end{array}$ & $12.1-22.2$ & - & - & - & $0.072-0.077$ & $461-523$ \\
\hline FAS 118 & 26.3 & $9.10 \mathrm{E}+03$ & $8.01 E+03$ & - & - & - \\
\hline $\begin{array}{l}\text { Station A, } \\
\text { CEMRC data* }\end{array}$ & $4.81-20.67$ & $1.37-5.14$ & - & $0.03-1.0$ & & \\
\hline $\begin{array}{l}\text { Station B, } \\
\text { CEMRC data* }\end{array}$ & $2.95-19.72$ & $0.94-5.47$ & - & $0.028-0.214$ & - & - \\
\hline $\begin{array}{l}\text { Station A, } \\
\text { NWP data }\end{array}$ & 1.63 to 27.62 & - & - & $\begin{array}{c}0.048 \\
(0.003-0.080)\end{array}$ & - & - \\
\hline $\begin{array}{l}\text { Station B, } \\
\text { NWP data }\end{array}$ & 5.13 to 18.03 & - & - & $\begin{array}{c}0.050 \\
(0.003-0.273)\end{array}$ & - & - \\
\hline
\end{tabular}

*Activity ratio ${ }^{241} \mathrm{Am} /{ }^{239+240} \mathrm{Pu}$ 


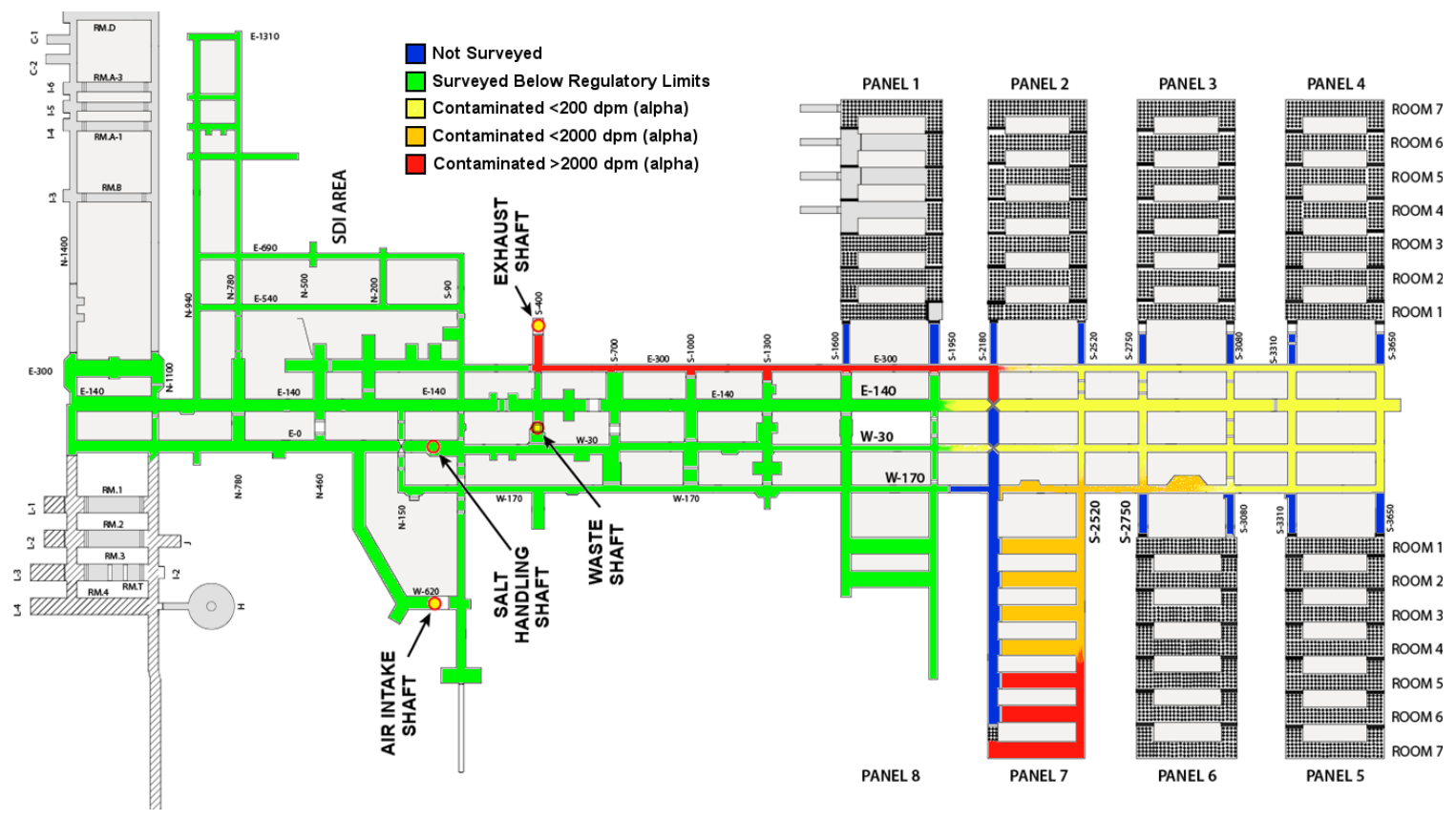

Figure 1. Contamination levels in the WIPP underground. 

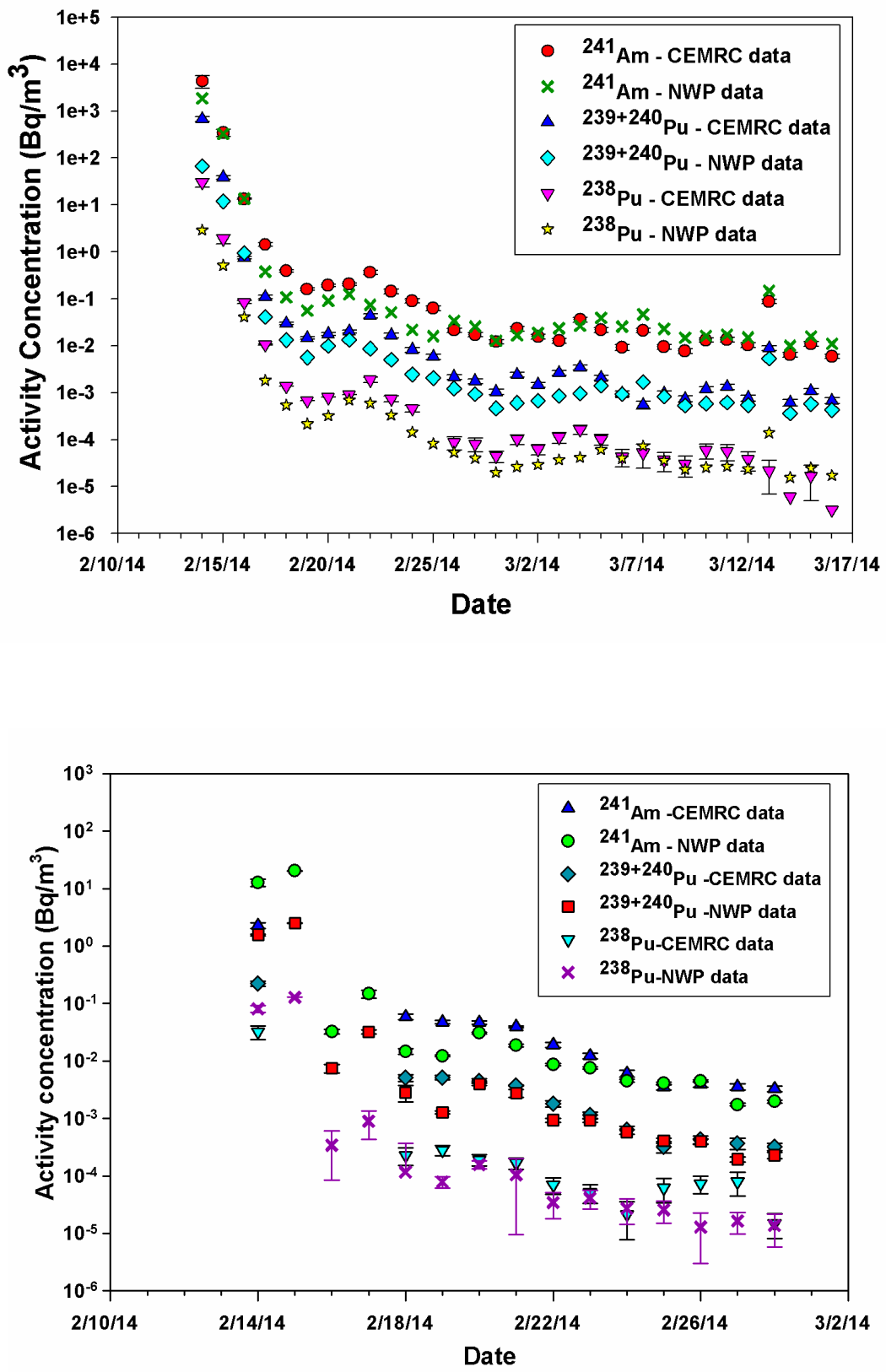

Figure 2. Concentrations of ${ }^{241} \mathrm{Am},{ }^{239+240} \mathrm{Pu}$ and ${ }^{238} \mathrm{Pu}$ in the filter sample collected from Station A (Pre-HEPA, Top) and Station B (Post-HEPA, Bottom) following the radiation release event at WIPP. 

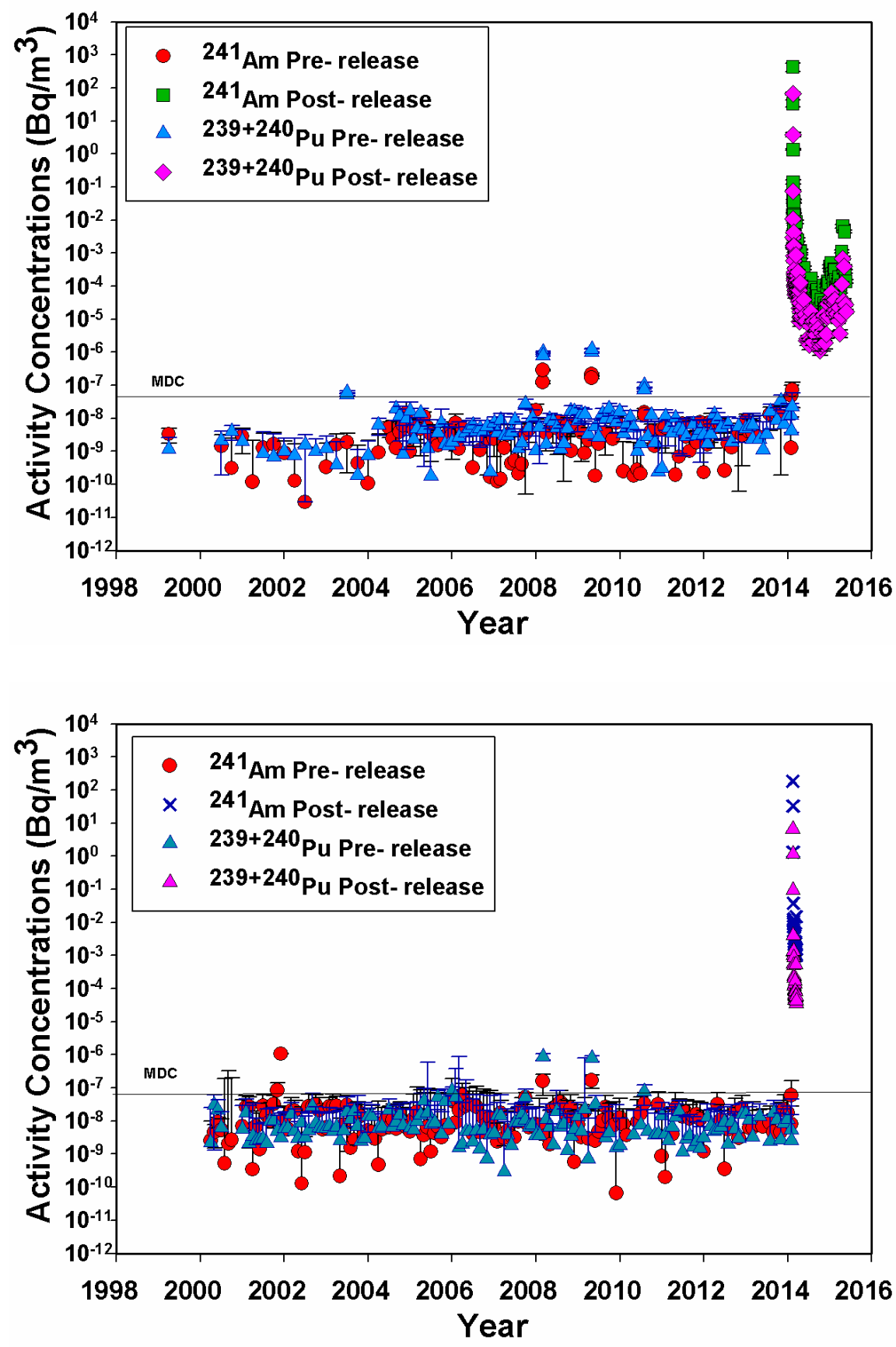

Figure.3. Pre- and post release ${ }^{239+240} \mathrm{Pu}$ and ${ }^{241} \mathrm{Am}$ concentrations in the WIPP underground air (Station A, Pre-HEPA), CEMRC data (Top) and NWP data (Bottom) 


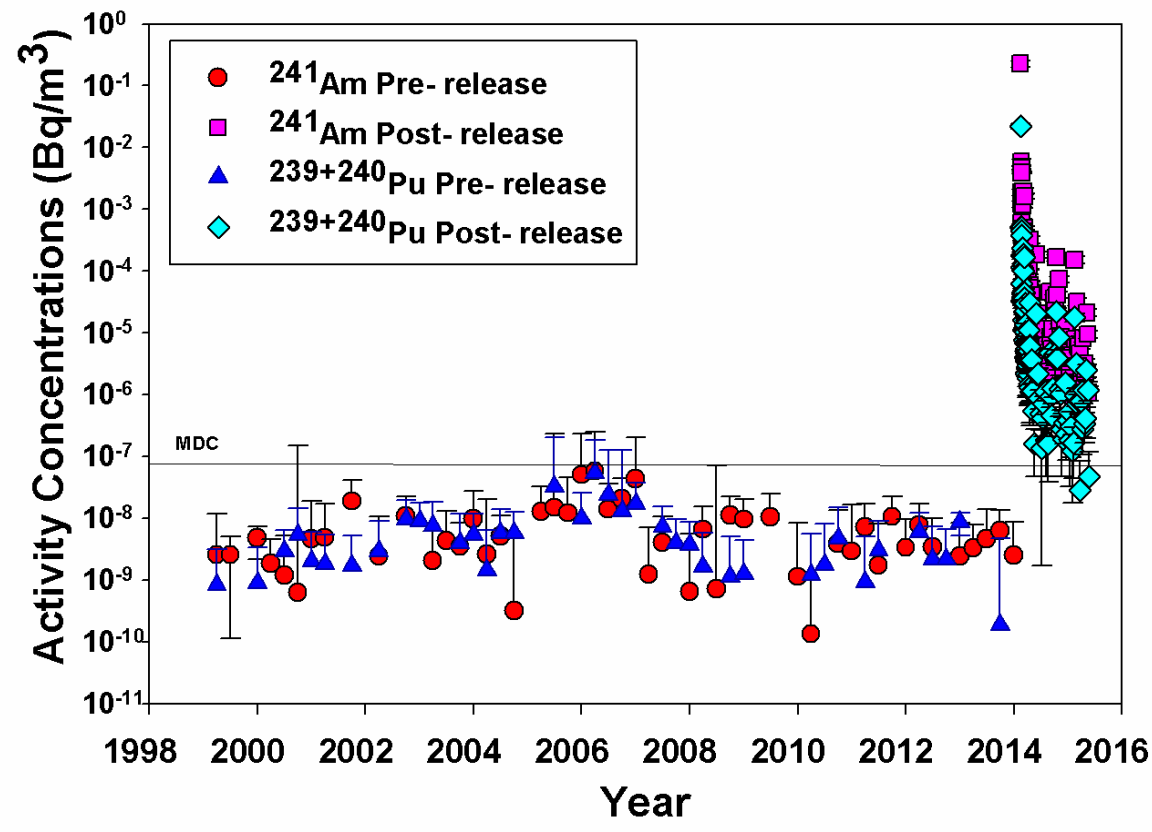

Figure.4. Pre- and post release event ${ }^{239+240} \mathrm{Pu}$ and ${ }^{241} \mathrm{Am}$ concentrations in the WIPP underground air (Station B, Post-HEPA) 

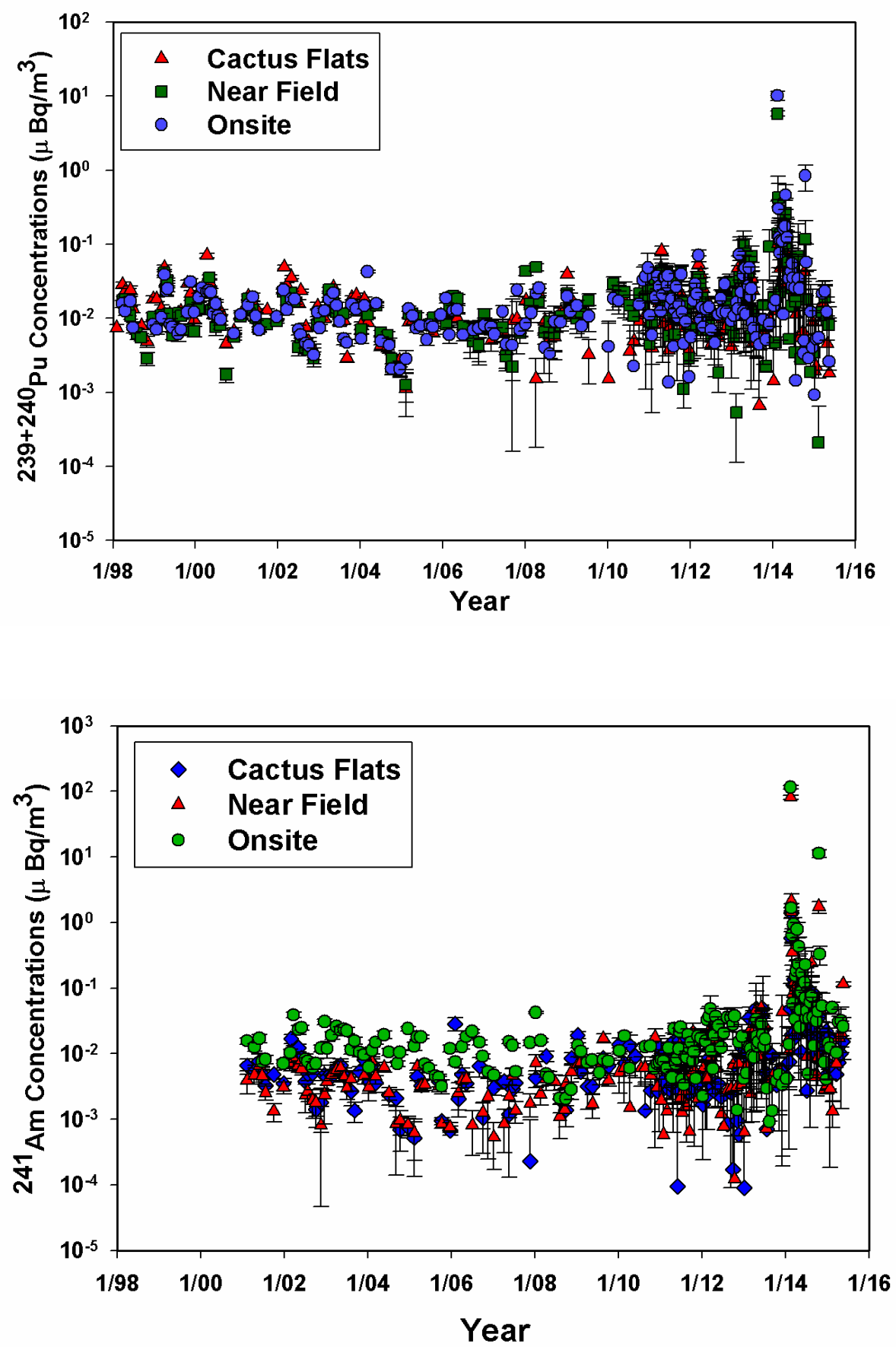

Figure 5: The ${ }^{239+240} \mathrm{Pu}$ and ${ }^{241} \mathrm{Am}\left(\mu \mathrm{Bq} / \mathrm{m}^{3}\right)$ concentrations in the ambient air in the WIPP vicinity measured by CEMRC. 


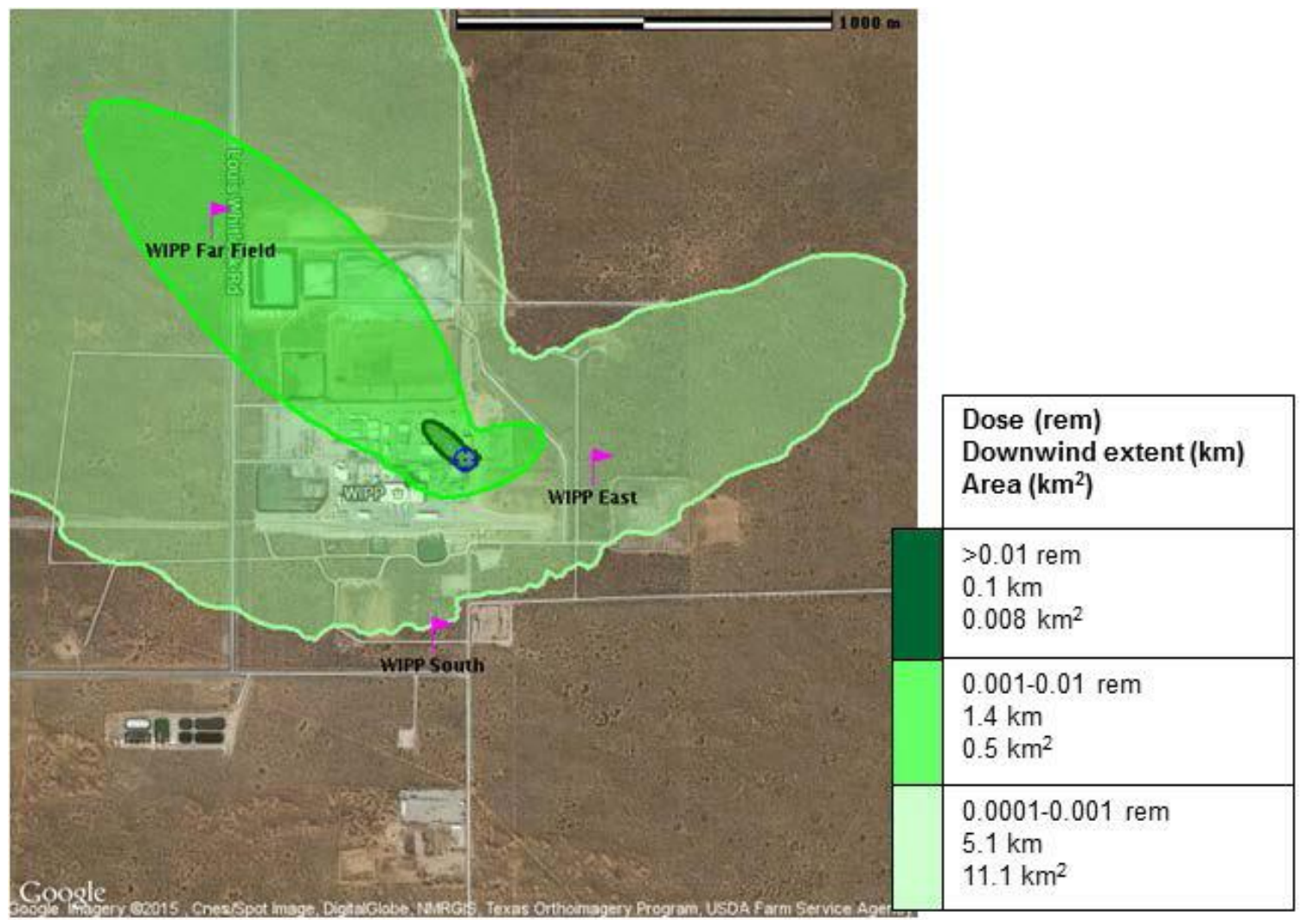

Figure 6. Potential dose reconstructions from the WIPP radiation release. 


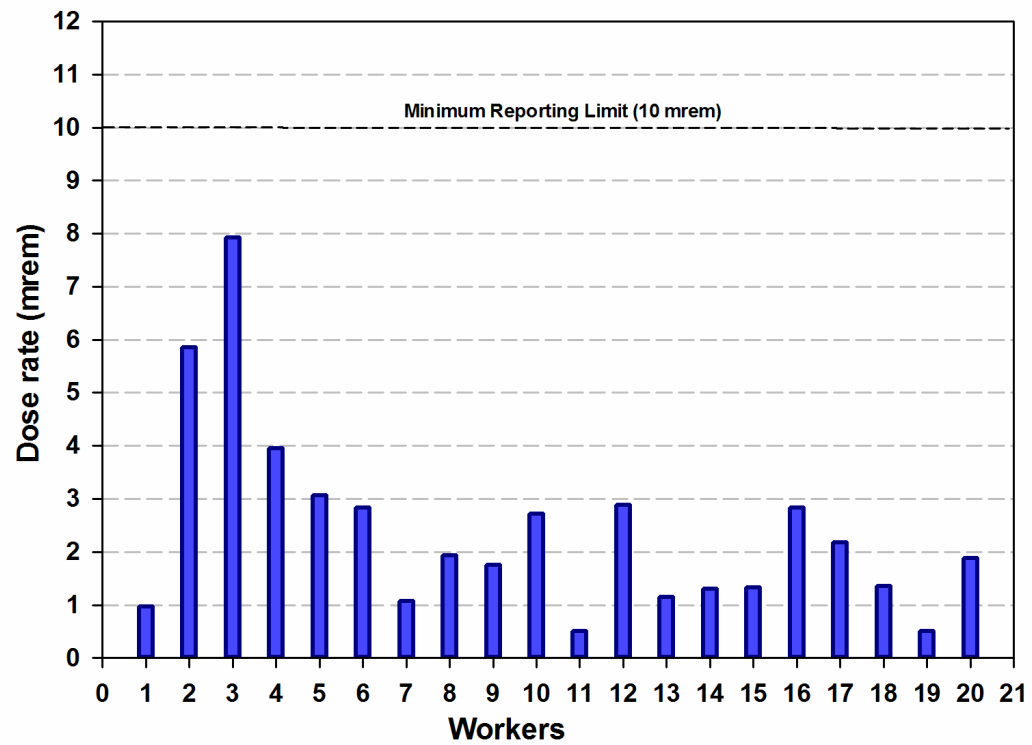

Figure 7. Dose received by the contaminated WIPP's workers following the radiation release event. 